\title{
European Cities as Command and Control Centres, 2006-11
}

\author{
G. Csomós ${ }^{*}$ and B. Derudder ${ }^{* *}$
}

\section{Introduction}

Since the mid-1980s, it has become increasingly popular to research contemporary economic globalization through the lens of cities (see, for instance, Friedmann, 1986; Sassen, 1991; Castells, 1996; Taylor, 2004). One strand of research thereby focuses on the global 'command-and-control function' of major cities, which is often measured through the presence of corporate headquarters of major multinational enterprises (MNEs; see, for instance, Godfrey and Zhou, 1999; Alderson and Beckfield, 2004; Taylor et al., 2009). Following this lead, this commentary has three related purposes. First, we aim to take stock of how European cities have fared as global command-and-control centres in the wake of the financial crisis in 2008 and the lingering Euro crisis throughout most of 2011. To this end, we explore the shifting positions of leading European cities in their role as MNE headquarter locations in the period 2006-11. Second, based on an interpretation of our empirical findings, we critically interrogate the conceptual purchase of mere MNE headquarter location as a measure of the command-and-control function of cities. And third, using Castells' (1992) work on the 'Informational City', we briefly explore the possible long-term consequences for European cities.

\section{Data and methodology}

We use data from the 'Forbes Global 2000' database for the years 2006 and 2011. This database contains information on the world's largest 2000 companies as measured by a composite ranking for sales, profits, assets, and market value. We concentrate on firms' turnover and market value, and assign this value to the companies' headquarter city as given in the Forbes database. Headquarter locations were thereby integrated into urban agglomerations as defined by the national statistical offices for reasons of consistency (corporate headquarters are frequently located in the wider metropolitan region of major cities). In addition, to avoid idiosyncratic results, we only included cities that had at least three company headquarters in either 2006 or 2011. About two thirds of the urban agglomerations were thus dropped because these only housed one or two company headquarters in both 2006 and 2011. However, underscoring the concentration of corporate power in a limited set of metropolitan regions, this reduction only caused a minimal reduction of the turnover and market value contained in the original data: in both cases more than $90 \%$ of the initial value is retained in the final dataset. A summary of the transformed data is given in Table 1. The number of firms thus fell to 1,722 in 2006 and to 1,680 in 2011, while the number of urban agglomerations fell to 151 (world) and 43 (Europe) respectively. The table already hints at the overall, relative decline of European cities in the global metropolitan system in this period. For instance, while the market value of the firms headquartered in Europe increased with $8.3 \%$ between 2006-2011, this stands at $19.3 \%$ for the firms headquartered in other parts of the world. 
Table 1: Summary of data used in the 2006-2011 comparison

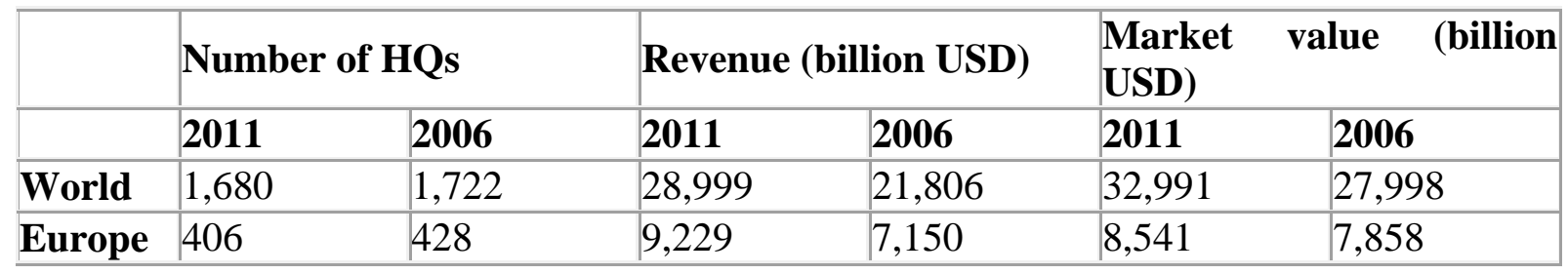

In order to explore change at the level of individual cities, two sets of calculations are required. First, for each city we calculated a single measure of 'command-and-control' $C A C$ through a linear combination of the percentage of headquarters, market value and turnover associated with that city in both 2006 and 2011. This combination of variables controls for situations where there is an imbalance of a given component, e.g. cities with few headquarters, but with major levels of turnover (or the other way round). Thus the CAC of Tokyo, still the dominant command-and-control centre in the global economy (Taylor and Csomós, 2012), fell from 10.3\% to 8.4\% between 2006 and 2011, while Beijing's CAC rose from $1.2 \%$ to $3.6 \%$ in the same period.

The second step is the calculation of a meaningful measure of CAC change. Although a straightforward way to gauge this change would be to simply look at the change in a city's CAC in and by itself, a better way to do this is to standardize the level of change viz. the overall change within the Forbes 2000 data. Mathematical details of this procedure can be found in Derudder et al. (2010), but the key point here in terms of interpretation is that the statistical distribution of CAC changeconforms to a standard normal distribution with an average value of 0 and a standard deviation of 1 . This has the distinct advantage that a city's $C A C$ change can basically be understood as a z-score. For instance, cities with an absolute value of $>2$ have witnessed 'exceptional' CAC change when cast in the context of overall changes in the level of headquarters, turnover and market value contained within the Forbes 2000 firms. Note that measures of CAC change depend on the reference framework: in contrast to percentage change, CAC values may change when cities are considered in a different spatial reference framework. For instance, given declining levels of CAC of European cities in the global economy (see below), a city such as Barcelona with a global $\mathrm{CAC}$ change of around 0 has a positive European CAC change.

\section{Results}

Before turning to geographical variegation within Europe, we look at some notable CAC changes from a global perspective. Figure 1 maps CAC change of the 151 cities in our data, while Table 2 lists the 10 cities with the most substantial positive/negative CAC change. In line with the anticipated geographical shift in the world-economy from 'West' to 'East' (e.g. Arrighi 1994; Frank 1998), Table 2 and Figure 1 suggest that especially Asian cities have acquired larger proportions of CAC, while particularly US and European cities have lost CAC. At the same time, however, the picture is much more variegated than a simple west-toeast shift (see also Derudder et al., 2011), with Tokyo and Osaka losing major shares of their CAC, Brazilian and Australian cities acquiring more CAC, and variegation within the US and Europe (e.g. Paris and Zug in Europe, and San Jose and Calgary in North America). San Jose, for instance, has seen a major increase in its level of CAC as information technology companies (with Apple as the prime, but not the sole example) headquartered in this city have dramatically increased their market value. It is, however, especially the three leading Chinese cities that have acquired more CAC functions. Beijing, for instance, housed the headquarters 
of a total of 15 firms in the Forbes list in 2006, representing a turnover of 203.99 billion USD and a market value of 468.41 billion US. In 2011, a total of 38 Forbes firms had their corporate headquarters in Beijing, representing a turnover of 923.02 billion USD and a market value of 1,734.90 billion USD. In general, then, changes in cities' CAC function seem to broadly replicate broader sea changes in the global economy, with European cities losing CAC over the global economy.

Table 2: Top 10 positive and negative values of CAC change in a global framework

\begin{tabular}{|l|l|l|l|l|}
\hline Rank & \multicolumn{2}{|l|}{ Top 10 positive changes } & \multicolumn{2}{l|}{ Top 10 negative changes } \\
\hline 1 & Beijing & 7.91 & Tokyo & -2.03 \\
\hline 2 & Hong Kong & 3.30 & Detroit & -1.55 \\
\hline 3 & Shanghai & 3.23 & London & -1.48 \\
\hline 4 & Seoul & 2.62 & New York & -1.46 \\
\hline 5 & Sao Paulo & 2.12 & Cincinnati & -1.44 \\
\hline 6 & Moscow & 2.12 & Philadelphia & -1.40 \\
\hline 7 & Mumbai & 1.80 & Amsterdam & -1.35 \\
\hline 8 & Paris & 1.33 & Osaka & -1.27 \\
\hline 9 & Rio de Janeiro & 1.24 & Atlanta & -1.10 \\
\hline 10 & San Jose & 1.01 & Richmond & -1.09 \\
\hline
\end{tabular}

\section{Figure 1: CAC change in a global framework}

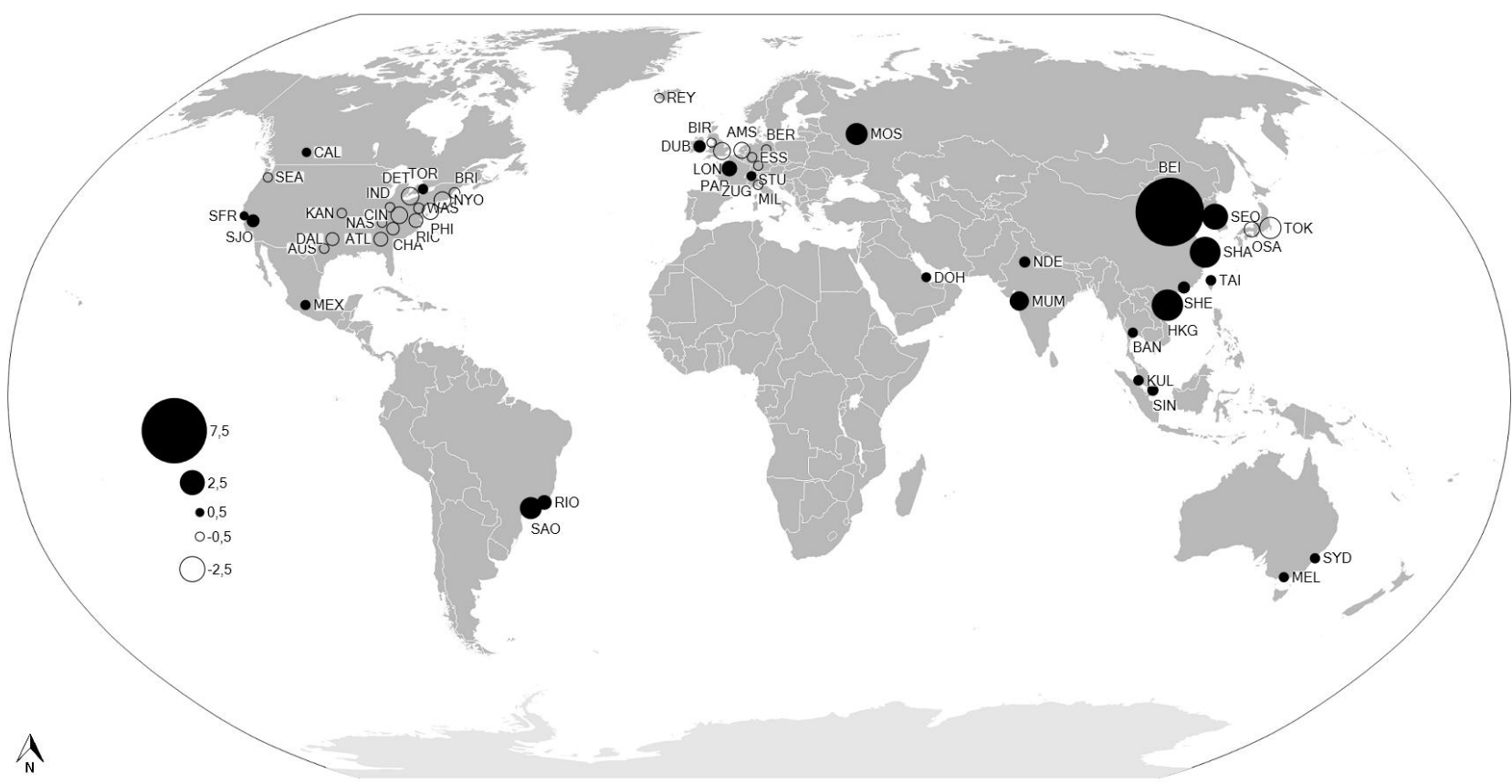

To paint a more detailed picture of the variegation amongst European cities, we recalculated CAC change in a European spatial reference framework. Figure 2 maps this CAC change, while Table 3 lists the 10 cities with the most substantial positive/negative CAC change. In line with changes at the global level (Table 2), especially Moscow and Paris have acquired more CAC functions in the context of the European metropolitan system. For instance, while the number of Forbes 2000 firms headquartered in Paris remained stable, these firms gained in market value $(+4 \%)$ and especially turnover $(+33 \%)$. The reason for this rise can be attributed 
to a mix of changes in the banking sector (e.g. BNP Paribas acquiring Fortis), energy firms banking on surging oil and gas prices (e.g. Total), and oligopolistic margins and global expansion of firms in utility sectors (e.g. GDF Suez and EDF Group). The rising market value and turnover of firms active in the energy is also the main driver of Moscow's growth: in 2006 only Lukoil and Gazprom featured in the Forbes 2000 list, while in 2011 the turnover and market value of five Moscow energy firms was included.

Meanwhile, the banking crisis has brought about some of the main significant drops in CAC. Reykjavik, for instance, headquartered in 2006 three banks listed in the Forbes ranking (Islandsbanki, Kaupthing Bank, Landsbanki Islands). Following the 2008 banking crisis, the Icelandic banking sector collapsed and all three banks dropped from the Forbes 2000 (Wade and Sigurgeirsdottir, 2012). London and Amsterdam have witnessed by far the largest drop in CAC. In both cases, this decline was especially due to the falling number of headquarters of firms listed in the Forbes dataset (e.g. from 87 to 65 for the London case), and also because major losses in the market value of banks.

In principle, the tables and maps presented here can be used as a general backcloth for reference in terms of changing CAC functions of and in the European metropolitan system as the consecutive financial crises morph into geographically uneven waves of economic recession in Europe. However, we emphasize that this structuralist account of the crisis is but one specific vantage point in the analysis of the spatial variegation of the impacts of the global financial crisis in Europe. Hadjimichalis (2011), for instance, presents a similar account from the perspective of socio-spatial justice and solidarity, while Smith and Swain (2011) explore models of development in Eastern Europe in the context of the crisis ${ }^{1}$.

Table 3: Top 10 positive and negative values of CAC change in a European framework

\begin{tabular}{|l|l|l|l|l|}
\hline Rank & \multicolumn{2}{|l|}{ Top 10 positive changes } & \multicolumn{2}{l|}{ Top 10 negative changes } \\
\hline 1 & Moscow & 3.79 & London & -2.59 \\
\hline 2 & Paris & 2.16 & Amsterdam & -2.13 \\
\hline 3 & Dublin & 1.84 & Milan & -0.84 \\
\hline 4 & Zug & 1.31 & Essen & -0.76 \\
\hline 5 & Luxembourg & 1.00 & Berlin & -0.73 \\
\hline 6 & Stockholm & 0.81 & Reykjavik & -0.72 \\
\hline 7 & Schaffhausen & 0.52 & Birmingham & -0.70 \\
\hline 8 & Lausanne & 0.41 & Stuttgart & -0.63 \\
\hline 9 & Munich & 0.34 & Madrid & -0.62 \\
\hline 10 & Vienna & 0.34 & Turin & -0.53 \\
\hline
\end{tabular}

Figure 2: CAC change in a European framework 


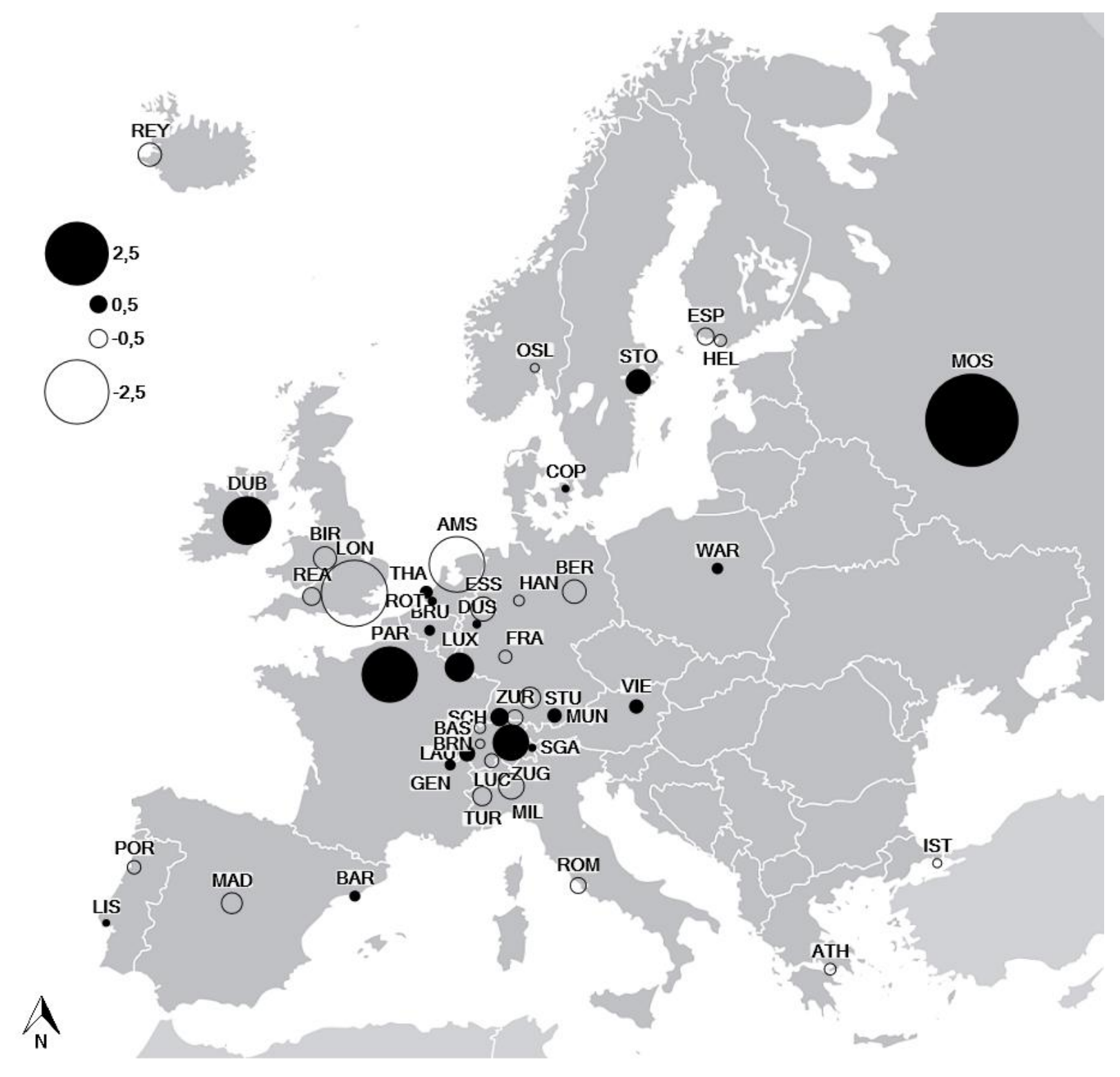

The headquarter conundrum

Over and above these formative interpretations, however, the results also suggest that CAC associated with MNE headquarters are perhaps (increasingly) unsuitable to understand the very concept of CAC in metropolitan systems. This point has been made earlier in conceptual and empirical terms. Allen (2010), for instance, has argued that the straightforward understanding of CAC as something that a city 'possesses' is conceptually untenable, while Godfrey and Zhou (1999) have shown that the inclusion of regional headquarter paints a more nuanced empirical picture of CAC in the global economy (see also Jones, 2002).

To these earlier observations, we would like to add the increasing significance of the separation between 'virtual' financial headquarters and 'actual' operational headquarters - it is the former that is being used by Forbes and in most empirical world cities research, while it is the latter that seems to be increasingly relevant. A key example is the takeover of American brewer Anheuser-Busch by Belgo-Brazilian brewer InBev. After the takeover, the 'official' corporate headquarters were retained in Leuven (Belgium) as a sign of respect for "the heritage, the source, the romance" of brewing (Modern Brewery Age, 2009), but the de facto 
functional global management office is now located in Manhattan, New York (http://www.abinbev.com/contact.cfm). Such a separation, we suggest, is increasingly popular, predominantly for fiscal reasons.

A number of examples from our analysis corroborate this reading. The CAC increase for Dublin, for instance, is very counterintuitive given Ireland's banking problems and deep recession. However, the doubling of 'Dublin headquarters' from 7 to 15 that underlying this increase is of course not related to the 'strength' of the Irish economy, but rather to its renewed and even increased role as a de facto tax haven (Dharmapala, 2008). While all Forbes firms in 2006 could be credibly suggested to have both their operational as well as financial headquarters in Dublin, in 2011 of the 15 firms 'officially' headquartered in Dublin three had their operational headquarters in the United States, three in the United Kingdom, while two United Kingdom firms which were originally registered in Bermuda re-registered in Dublin (i.e. Accenture and Ingersoll-Rand).

The same processes explain the artificial rise of Luxemburg as well as Zug and Schaffhausen in Switzerland. The latter examples, however, show that this bifurcation has even reached the point that the link between metropolitan economies and CAC is increasingly becoming a fictional data feature more than anything else. The case of Zug was recently described in Time Magazine (2010). It was shown that literally thousands of companies have recently 'arrived' in the sleepy provincial town, including giant MNEs such as Biogen (a Massachusetts-based biotech giant) and Transocean (the world's biggest offshore-oil-drilling contractor). Yet both firms continue to run their business from Boston and Houston, respectively. The crux is that Swiss officials 'assume' that foreign companies pay taxes where they produce, while the 20-minute train trip to Zurich suffices to reach sophisticated - and discreet - banks. However, even this trip is often unnecessary, ,since their 'headquarters' exist entirely within the stolid post office building, whose hall holds thousands of postboxes retained by foreign companies" (http://www.time.com/time/magazine/article/0,9171,2040142,00.html).

In the past world city scholars could treat firms headquartered in the Cayman Islands, Bermuda or Liechtenstein as 'exceptions' because these were essentially offshore constructions. However, the 'optimization' of corporate structures to minimize, or even totally evade, corporate tax, seems to have prompted a broader movement towards a distinction between operational and 'official' headquarters. In addition to changes in the European metropolitan system of MNE-produced CAC, then, our calculations increasingly measure specific features of corporate structures. Combined with the insights of Godfrey and Zhou (1999) and Allen (2010), then, a key question for world city scholars is at what point this distinction becomes so widespread that it totally disallows analyses such as those by Alderson and Beckfield (2004) and Taylor et al. (2009).

\section{Conclusions: the future(s) of European cities}

Dunford and Yeung (2011) recently pointed out that the combination of a faltering European economic recovery on the one hand, and a sustained economic growth of China and other emerging economies on the other hand has the potential to profoundly alter a number of global imbalances. They suggest that if the situation that has emerged between 2008 and the time of writing of this commentary persists, we may even see a reverse in the economic gaps created by the combined effect of the industrial revolution, colonialism and imperialism. Although these global imbalances have been so profound for so long now that an actual 
reverse is not on the immediate horizon, it is clear that the global financial crisis has indeed been acting as a major catalyst for a larger geo-economic sea change with Europe on the losing end. These changes have myriad different causes and implications, but in this commentary we have restricted ourselves to a straightforward description of one particular example: the (changing) degree to which European cities are functioning as the territorial platforms from which the world's major MNEs are being run. In spite of the caveats of this analysis (e.g. the financial/operational HQ distinction, the problem of the myth of 'global management' as emphasized by Jones (2002), etc.), our results clearly expound the declining command-and-control capacity of most European cities.

What are the potential consequences for European cities if this decline persists? In his wellknown treatise of the 'Informational City', Castells (1992, see also 1996 and 2002 for a follow-up and a deepening of the argument) argues that throughout the last two decades of the 20 th century and the beginning of the 21 st century, a whole matrix of social and economic trends have (unevenly) restructured European cities. A key change, according to Castells (2002), was the emergence of firms and other key actors that used cities' informational potential and new communication technologies to extend and deepen their global reach, which has in turn been facilitated by ever-increasing deregulation throughout the global economy. This has resulted in the rise of a number of cities that are 'successful' in the advanced producer services economy and high technology manufacturing, while some old dominant industrial regions have not been able to make such transition to the informational economy. Castells emphasizes that the 'Informational City' is closely related to the 'Global City' concept aka the command-and-control centres explored in this paper, as this articulates the directional functions of the global economy in a network of decision-making and information processing centres. And finally, and as frequently debated in the urban literature (see Sassen, 1991; Hamnett, 1996), the 'Informational City'/'Global City' also became an increasingly 'Dual City' in that these processes inhibit a structural tendency to generate a polarized occupational structure, broadly in line with the informational capabilities of different social groups.

Given the decline of European cities as command-and-control centres, we may well be on the verge of a new matrix of social and economic trends that will once again (unevenly) restructure European cities. The closely inter-related concepts of Informational City/Global City/Dual City may therefore and thereby no longer be the most appropriate background for conceptualizing urban processes in Europe's major metropolitan centres: if the spatial evolution of European cities is indeed a historically specific expression of a broader structural transformation of urban and economic forms and processes, it is likely that European cities are facing some significant transformations.

\section{REFERENCES}

Alderson, A.S. and Beckfield, J. (2004) Power and Position in the World City System. American Journal of Sociology 109: 811-51.

Allen, J. (2010) Powerful City Networks: More than Connections, Less than Domination and Control. Urban Studies, 47, 2895-2911.

Arrighi, G. (1994) The long twentieth century: money, power, and the origins of our times. Verso, London. 
Benediktsson, K., Karlsdóttir, A. (2011) Iceland: crisis and regional development - thanks for all the fish? European Urban and Regional Studies, 18(2), 228-235.

Blažek, J., Netrdová, P. (2011) Regional unemployment impacts of the global financial crisis in the new member states of the EU in Central and Eastern Europe. European Urban and Regional Studies, 19(1), 42-61.

Castells, M. (1992) The Informational City: Economic Restructuring and Urban Development. Oxford: Blackwell.

Castells, M. (1996) The Rise of the Network Society. Oxford: Blackwell.

Castells, M. (2002) Local and Global: Cities in the Network Society. Tijdschrift voor Economische en Sociale Geografie, 93(5), 548-558.

Derudder, B., Taylor, P.J., Ni, P., De Vos, A., Hoyler, M., Hanssens, H., Bassens, D., Huang, J., Witlox, F., Shen, W., Yang, X. (2010) Pathways of Change: Shifting Connectivities in the World City Network, 2000-08. Urban Studies, 47(9), 1861-1877.

Derudder, B., Hoyler, M., Taylor, P.J. (2011) Goodbye Reykjavik: international banking centres and the global financial crisis. Area, 43(2), 173-182.

Dharmapala, D. (2008). What problems and opportunities are created by tax havens? Oxford Review of Economic Policy, 24(4), 661-679.

Dunford, M., Yeung, G. (2011) Towards global convergence: Emerging economies, the rise of China and western sunset? European Urban and Regional Studies, 18(1), 22-46.

Frank, A.G. (1998) ReORIENT: global economy in the Asian age University of California Press, Berkeley

Friedmann, J. (1986) The World City Hypothesis. Development and Change, 17, 69-84.

Godfrey, B.J., Zhou, Y. (1999) Ranking World Cities: Multinational Corporations and the Global Urban Hierarchy. Urban Geography, 20, 268-281.

Hadjimichalis, C. (2011)Uneven geographical development and socio-spatial justice and solidarity: European regions after the 2009 financial crisis. European Urban and Regional Studies, 18(3), 254-274.

Hamnett, C. (1996) Social Polarisation, Economic Restructuring and Welfare State Regimes. Urban Studies, 33(8), 1407-1430.

Hines, J.R., Rice, E.M. (1994) Fiscal Paradise: Foreign Tax Havens and American Business. The Quarterly Journal of Economics, 109(1), 149-182.

Jones, Andrew M. (2002) The 'global city' misconceived: the myth of 'global management' in transnational service firms. Geoforum 33 (3), pp. 335-350. 
Kinsella, S. (2012) Is Ireland really the role model for austerity? Cambridge Journal of Economics, 36(1), 223-235.

Sassen, S. (1991) The Global City. Princeton, Princeton University Press.

Smith, A. and Swain, A. (2010) The global economic crisis, Eastern Europe and the former Soviet Union: models of development and the contradictions of internationalization. Eurasian Geography and Economics, 51(1), 1-34.

Taylor, P.J. (2004) World City Network: A Global Urban Analysis. Routledge, London-New York, 1997.

Taylor, P.J., Ni, P., Derudder, B., Hoyler, M., Huang, J., Lu, F., Pain, K., Witlox, F., Yang, X., Bassens, D., Shen, W. (2009) The way we were: command-and-control centres in the global space-economy on the eve of the 2008 geo-economic transition. Environment and Planning A 41(1) 7-12.

Taylor, P.J., Csomós, G. (2011) Cities as control and command centres: Analysis and interpretation. Cities, doi:10.1016/j.cities.2011.09.005.

Wade, R.H., Sigurgeirsdottir, S. (2012) Iceland's rise, fall, stabilisation and beyond. Cambridge Journal of Economics, 36(1), 127-144.

\section{NOTES}

* György Csomós, Faculty of Engineering, University of Debrecen, Debrecen, Hungary; email: csomos@eng.unideb.hu

林 Ben Derudder, Geography Department, Ghent University, Belgium. Email: ben.derudder@ugent.be

1. In addition, there have been analyses of the shifting geographies of (un)employment in the wake of the crisis, such as those by Benediktsson and Karlsdóttir (2011, Iceland) and Blažek and Netrdová (2011, Central and Eastern Europe) the global financial crisis. 